\title{
ワイパブレードラバーの役割と機能について
}

小林陽*

\section{Role and Function of Wiper Blade Rubber}

Akira KOBAYASHI (Fukoku Co.,Ltd., 6 Showa, Chiyoda-machi, Oura-gun, Gunma, 370-0723, Japan)

Wiper blade rubber is a very important part in the automotive wiper system. Wiper blade is used under the severe environment, then many characteristics are required besides wiping ratio, low-abrasion, low-friction, low-deformation and so on. To satisfy the function, besides the rubber material, surface treatment and coating are also important technologies.

Key Words : Wiper Blade, Blade Rubber, Automotive Parts, Friction, Abrasion, Deformation

\section{1.は じ め に}

自動車用ワイパの歴史を顧みると，1903年頃は運転者 が室内から手動でレバー軸を介してワイパブレードを作動 させ，ガラス表面を払しょくしていた，その後1920年に TRICO 社が動力源にエンジンの吸気圧を利用した吸気式 モーターを実用化し，続いて1922年頃にはBOSCH社によ りバッテリーを動力源とする電気式ワイパモーターが開発 実用化された1).

その後, ワイパブレードを作動させる動力・機構・ワイ パブレードの構造・形状等が工夫改善されてきたが，自動 車のガラス表面に付着した雨水・泥水・雪・ほこりなどを ぬぐい取る手段としての基本原理は大きくは変わっていな い.

ここではワイパシステムの構成, 役割, そこに使われる ワイパブレードラバー(以下ブレードラバー)の役割と機能 について述べる。

\section{2. ワイパの構成と役割}

ワイパシステムは，ワイパモーターの回転運動をリンク 機構を介してワイパアームに伝達させる.ワイパアームは 扇形に往復運動し，その先端に取り付けられたワイパブレ ードがガラス面を払しょくし，ガラス表面に付着した雨 水・泥水・雪・ほこり等をぬぐい取る(図 1 , 図 2 ).

ワイパブレードにはワイパアームから所定の圧力がかか り，バーティブラ(板バネ)により圧力を均一化してブレー ドラバーを加圧する(図 3 ).

実際にガラス表面を払しょくするのはワイパブレードに
取り付けられたブレードラバーであり，ブレードラバーは

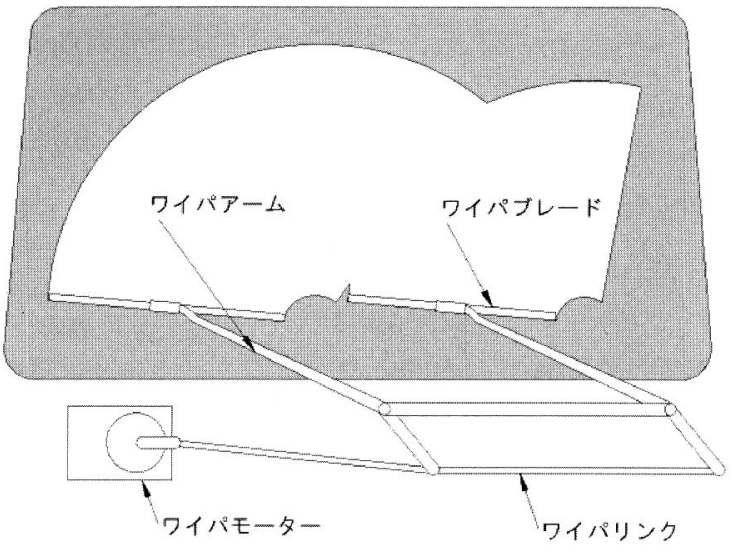

四 1 ワイパシステム

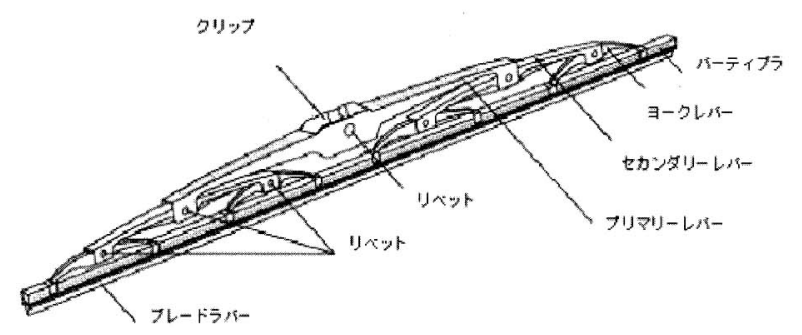

図 2 ワイパブレード(トーナメント構造)

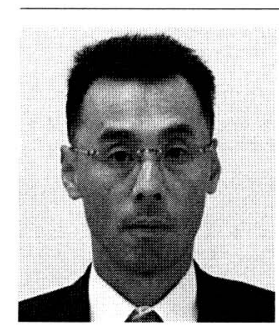

*(株)フコク技術本部, 機能品技術部ワイパー技 術課 (テ370-0723 群馬県邑楽郡千代田町昭 和 6 番地) マネジャー. 昭和 57 年, 成蹊大学 工学部工業化学科卒業. 同年, 富国ゴム工業 (株)(現, 株)フコク) 入社, 現在に至る。専門は, ゴム・エラストマー物性. 


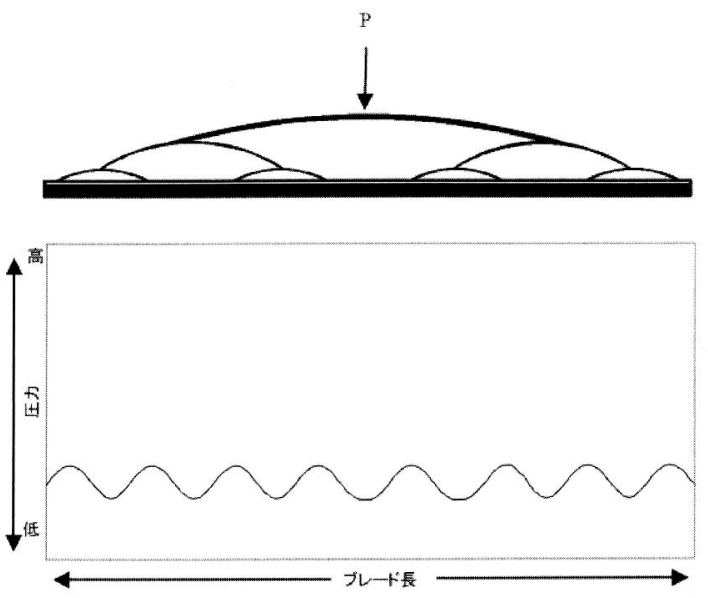

図 3 ワイパブレード (トーナメント構造)の圧力分布

ワイパシステムの中でも非常に重要な部品といえる.

\section{3. ブレードラバー}

ブレードラバーはアームからの圧力を受け, 常時ガラス に加圧されている．ブレードラバーとガラスとの接触幅は 約 $10 \mu \mathrm{m}$ であり，その圧力は $1.3 \sim 2.0 \mathrm{MPa}$ となり，自動 車夕イヤの数倍以上である.夕イヤの転がり摩擦に対して, ブレードラバーは潤滑摩擦と時には摩耗の激しい凝着摩 擦 ${ }^{2}$ を繰り返す。更に日光 (紫外線) ・ 熱・酸素 $\left(\mathrm{O}_{2}\right) \cdot$ オ ゾン $\left(\mathrm{O}_{3}\right)$ ・雪や砂塵などにさらされ, かなり過酷に使用 される部品の一つである.

\section{1 ブレードラバーの要求特性}

前記のような環境下で使用されるブレードラバーには， 種々の要求特性があり, それを満足させるために, 今まで さまざまな材質・表面処理および形状が検討されてきた. 以下にブレードラバーの要求特性について述べる.

3.1 .1 払しょく性 払しょく性はブレードラバーの最 も重要な基本特性である。ブレードラバーはガラス面でス ムーズに作動し，雨水を払しょくする，そのためリップ部 先端のエッジ部が直角であり，長手方向に直線的でなけれ ばならない.エッジ部に異物や欠けによる凹凸があると払 しょく性は満足しない(図 4)。一般にエッジ部に凹凸があ った場合,その大きさの約 10 倍の幅で払しょく性のスジ残 りが発生するといわれている(図 5 ).

また,払しょく時の水膜をできるだけ薄くし, 視界を確保

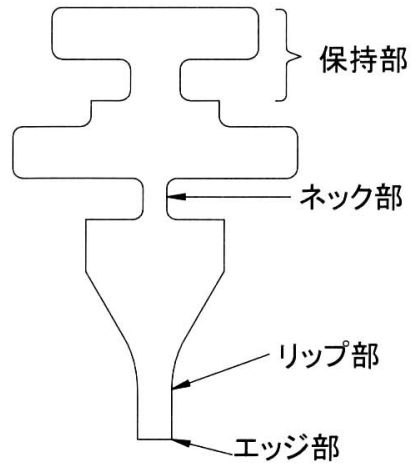

図 4 ブレードラバーの断面図
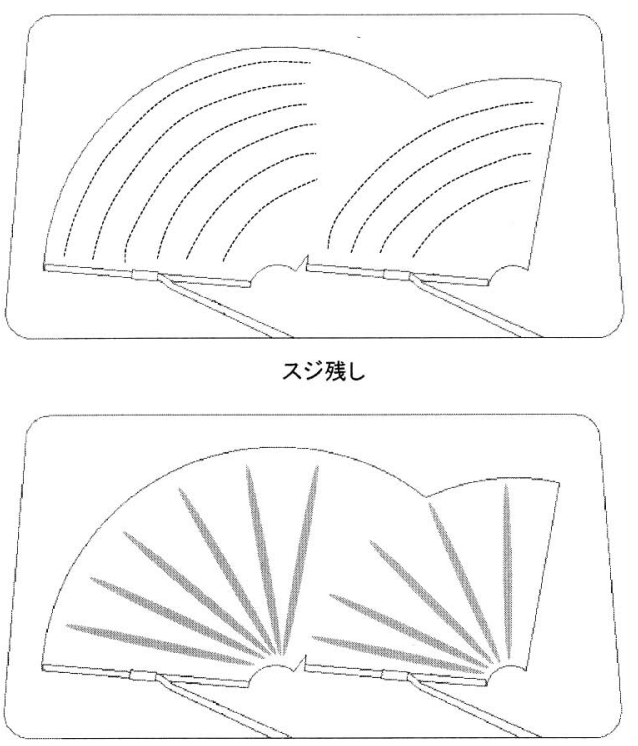

ビビリによるふき不良

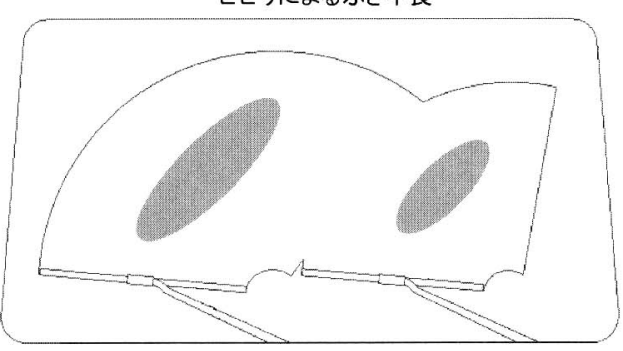

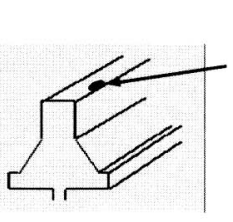

異物
浮きによるふき不良

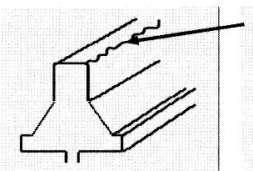

直線性 悪

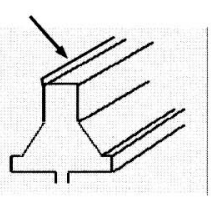

バリ
図 5 ふき残しパターン

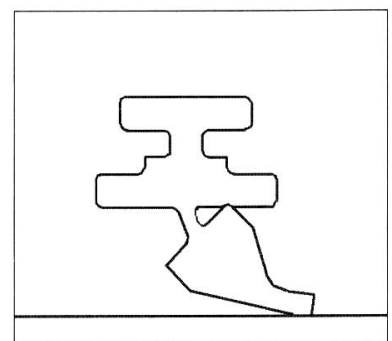

倒れ過ぎ

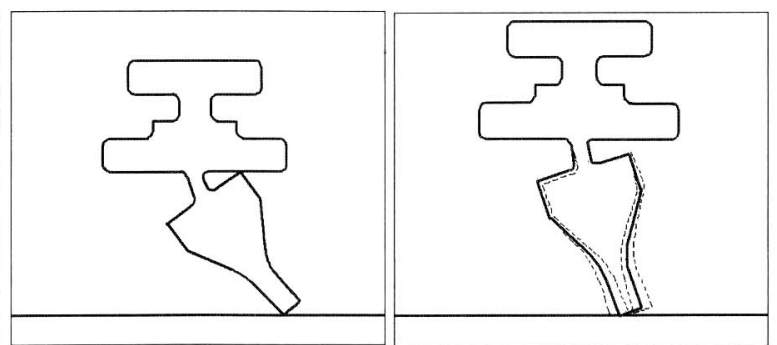

最適 $\left(45^{\circ}\right.$ 前後)
立ち過ぎ

図 6 ブレードラバーの接触角 

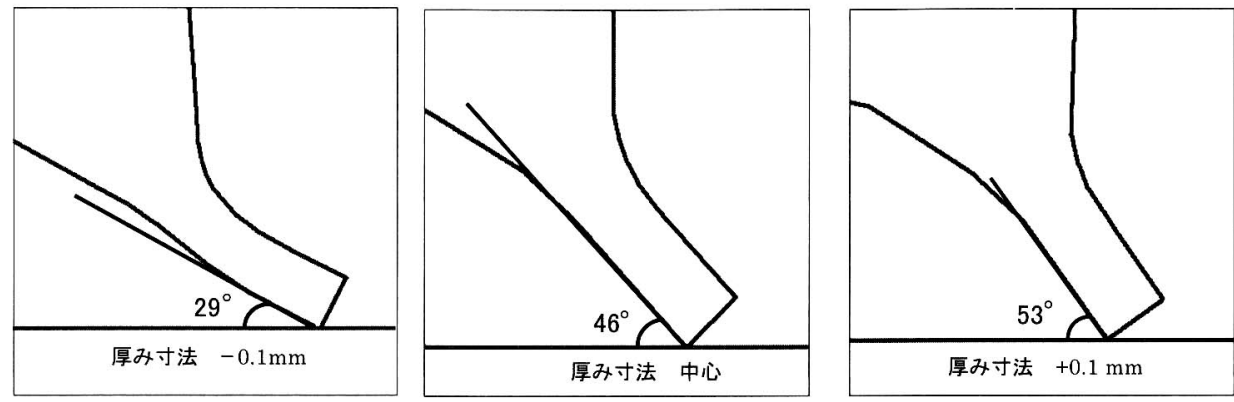

図 7 厚み寸法違いによる接触角（シミュレーション）

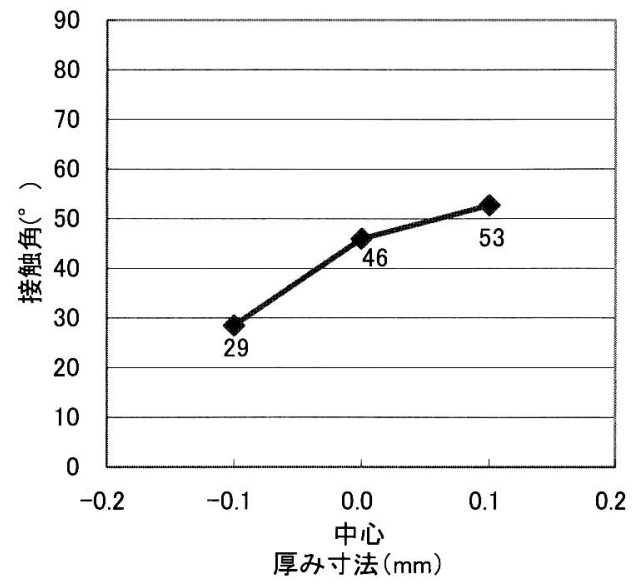

図 8 厚み寸法違いによる接触角の変化（シミュレーション）

するためには,ガラスに対する接触面圧力が高い方が有利 である．したがって，先に述べた接触幅 $10 \mu \mathrm{m}$ を維持する にはリップ部とガラス面との接触角 (以下接触角)が適切で ある必要がある。適切な接触角とは $45^{\circ}$ 前後とされてお $り^{3,4)}$ ，お抢よそ $20^{\circ}$ 以下になるとリップ部側面がガラス 面にあたることにより接触面圧が低下し水膜が厚くなり，

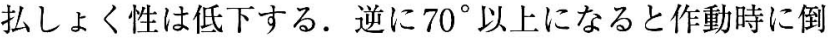
れが安定せず，スティックスリップ現象 ${ }^{5)}$ (以下ビビリ現 象)が発生する場合がある(図 6 )。この接触角がブレード の長手方向全体で大きな変化があってはならない．また， 気温の変化, 特に低温時も柔軟性を維持し, 一定の接触角 であることが望まれる。

また，寸法精度も重要な要素である．任意の形状でリッ プ部の厚みとネック部の厚みを中心に対して $0.1 \mathrm{~mm}$ シミュレーションを行った結果を図 7, 図 8 に示す.リッ プ部の厚みとネック部の厚みが中心の場合，接触角は $46^{\circ}$ であったが， $00.1 \mathrm{~mm}$ の範井では接触角は $29^{\circ}$ $53^{\circ}$ まで変化しうるという結果である.

3.1 .2 静肃性 ブレードラバーはガラス面上をスムー ズに動き，ビビリ現象や異音があってはならない。近年， 自動車室内の遮音性が高くなってきており，フロントガラ スから直接伝わる音は運転者に不快感をもたらす。そのた め静肃性も重要な特性といえる。

作動時の音に対して重要な要素は，適度な摩擦抵抗であ
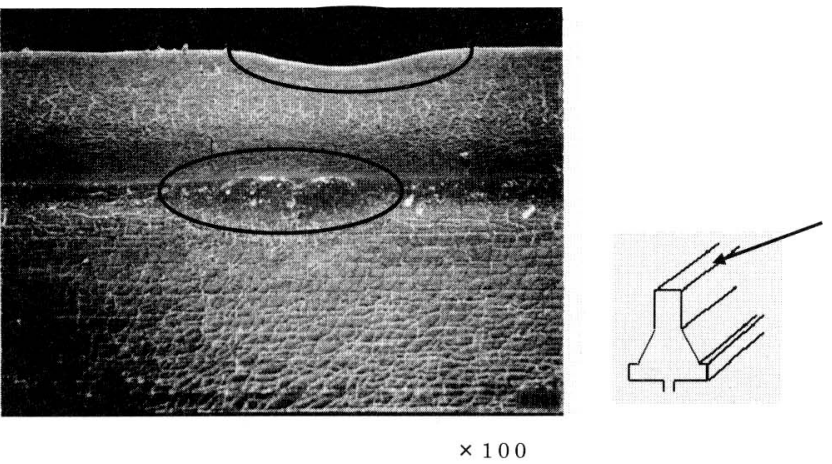

図 9 エッジ部の偏摩耗䇢所

ることである．摩擦抵抗が高い場合，ワイパブレードが飛 び跳ねて大きなビビリ音を発生する場合がある．また，通 常の雨で使用するほか小雨のようなガラス面がセミドライ 状態で使用すること，及びガラス面のほこりをウォシャー 液を使用してぬぐい落とす場合もある，そのため，ウェッ 卜状態 (流体摩擦領域)に対してセミドライ (混合摩擦から 境界摩擦領域)やドライ(乾燥摩擦領域)の状態6)でも摩擦 係数が大幅に増加してはいけない。

ブレードラバーの音にはビビリ音・作動時の擦れ音のほ かに反転時の反転音もある。摩擦抵抗を下げてビビリ音・ 作動時の擦れ音を低減したり，ブレードラバーの形状によ り反転音を低滅させる方策が取られるようになってきてい る.

3.1.3 初期性能の維持 初期性能とは, 主として払し ょく性・摩擦抵抗が挙げられる。払しょく性では，耐摩耗 性とその摩耗形態が重要である。耐摩耗性が良くないと早 期にエッジが摩耗し，払しょく性は低下する。また，長手 方向で全般的には摩耗は少ないものの, 部分的に摩耗が多 い, いわゆる偏摩耗の状態でも払しょく性は低下する，偏 摩耗の要因には, ブレードラバー内部の異物やカーボンブ ラックの分散不良により, その部分が欠落して偏摩耗を起 こすようなゴムに起因するものもあるが，ガラス面に付着 したタールやピッチならびに鳥のふんの上をワイパブレー ドが作動する事により，偏摩耗が起こることも多く，ブレ ードラバーの方からでは対応できない現象もある(図 9 ).

また，変形により接触角が大きく変化してはならない. ブレードラバーは使用せずにガラス面に圧着されている時 
間が圧倒的に長いため，使用する際変形により接触角が変 化し，ビビリ現象が発生したり，より変形量が大きい場合 には，反転不良が発生しワイパブレードが飛び跳ねる場合 もある。

ブレードラバーはネック部の厚みは $0.4 \sim 0.5 \mathrm{~mm}$, リッ プ部の厚みは $0.6 \sim 0.7 \mathrm{~mm}$ が一般的であり, これらの部分 は応力集中しやすく, 早期にオゾンき裂が発生しないよう な配慮が必要である。

3.1 .4 周辺への影響 自動車の塗装に対して污染性が ないことが必要である. 特に白色系のボディ塗装に対して ブレードラバー中の老化防止剤が雨水やウォシャー液等で 抽出され，污染しないように注意が必要である。また，ゴ ム材中の硬い異物やブレードラバーのはずれやちぎれによ り, 金具がガラスに当たってガラスを傷つけてはいけない. この他に急激な摩擦抵抗の増加は, ワイパモーターをロ ックさせる場合があるので, 注意しなければならない.

\section{2 ブレードラバーのゴム材について}

以上のようにブレードラバーの要求特性から，ゴム材と しては, 低摩耗・低変形ならびに耐オゾン性・低温性・耐 污染性が良好であることが挙げられる。

ポリマーとしては天然ゴム (NR)が多く使用されている が，耐候性・変形性を考慮してクロロプレンゴム $(\mathrm{CR}) を$
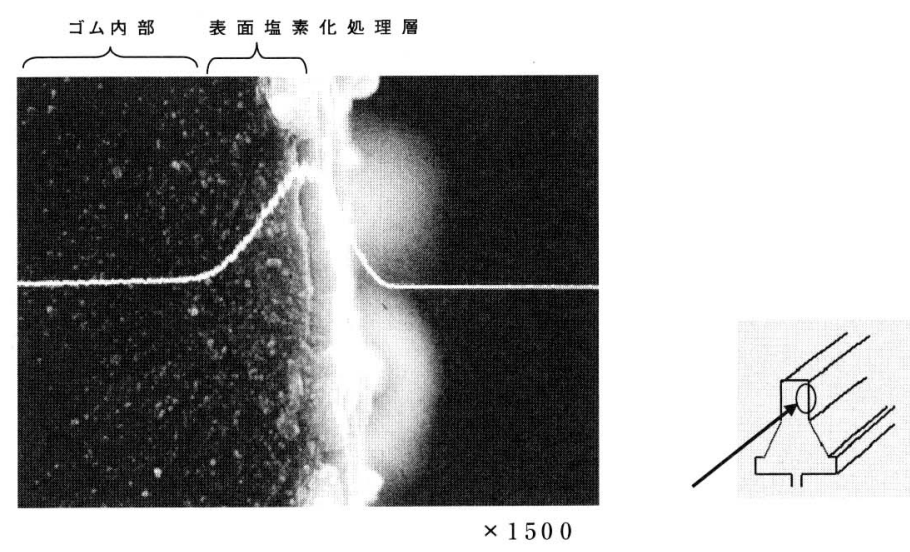

図10 ゴム表面の塩素の確認 EPMA, SEM像+線分析

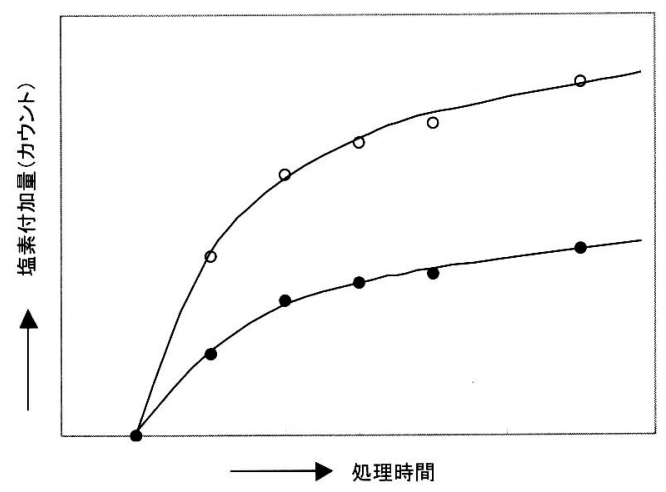

$(\mathrm{O}: \mathrm{NR}, \bigcirc: \mathrm{CR} / \mathrm{NR}=50 / 50$, 塩素ガス濃度 $50 \mathrm{vol} \%$, 蛍光 X 線条件: 照射面積 $0.9 \mathrm{~cm}^{2}$, 管球電圧 $50 \mathrm{kV}$, 管球電流 $40 \mathrm{~mA}$, 照 射時間 $10 \mathrm{~s}$ )

図 11 塩素ガス処理による塩素付加量と処理時間の関係
NRにブレンドしたものや，摩耗性を考慮しスチレンブタ ジエンゴム $(\mathrm{SBR})$ をR にブレンドしたものもある. 最近, はっ水のガラス面用としてシリコーンゴムも使用されるよ うになってきた。

\section{3 ブレードラバーの摩擦について}

これまで述べてきたように，ガラス面上を作動するブレ ードでは, 摩擦抵抗は重要な要素である.ここでブレード ラバーの摩擦についてもう少し詳しく述べる.

ブレードラバーの摩擦抵抗は，高すぎる場合にはワイパ モーターがロックする場合もあるし，モーターロックに至 らない場合でもビビリ現象が現れる場合がある．また，摩 擦抵抗が高ければ摩耗の進行も早くなる。

ブレードラバーの摩擦抵抗を下げる手段としては，ハロ ゲン化に代表される化学的表面処理とコーティングのよう な物理的処理がある。

\section{3 .1 ハロゲン化処理 ハロゲン化処理については,} 1988年 Gladstone ${ }^{7)}$ により報告されて以来, 多くの研究が なされてきた ${ }^{7-9)}$ 。 ハロゲン化処理の代表的なものに塩素 化処理がある. EPMA分析では塩素は表面から約 $10 \mu \mathrm{m}$ の範囲に分布しており，表面の $2 \sim 4 \mu \mathrm{m}$ が硬化膜となっ ていることがわかる(図 10)，塩素は付加量の増大に伴い 摩擦係数の低減効果がある(図 11, 図 12)。ただし, 塩素

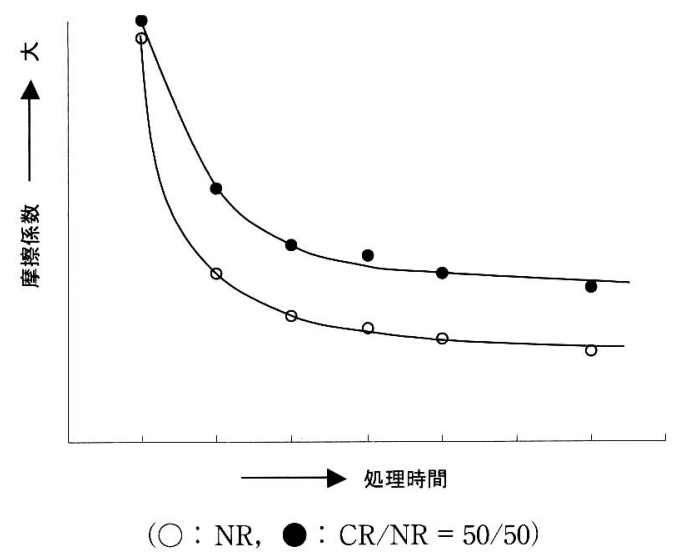

図 12 摩擦保数と処理時間の関係

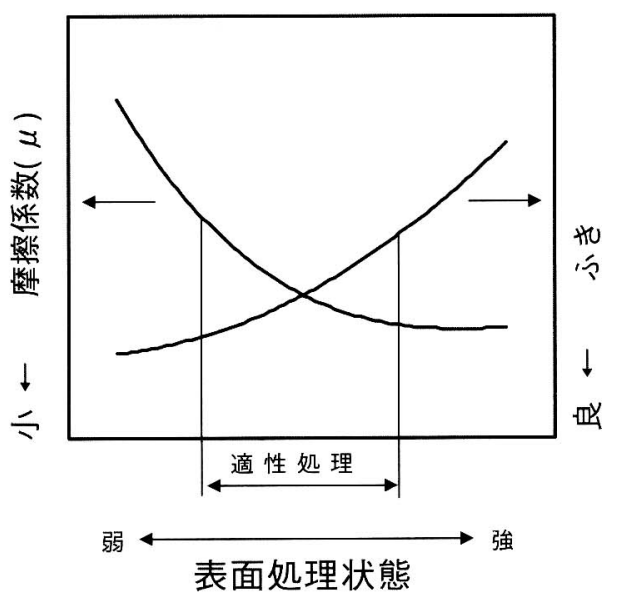

図 13 摩擦係数，ふきレベルと表面処理状態の関係(概念図) 
の付加量が多くなると適正なガラス面との接触角が保てな くなったり，表面硬化によりガラス曲面への追従が悪くな り，払しょく性が低下する．したがってハロゲン化処理は 摩擦係数と払しょく性を考慮して適正な幅で管理しなけれ ばならない(図 13).

3.3.2 コーティング 近年, 低摩擦化や低摩擦の長寿 命化を目的にハロゲン化処理のみでなくコーティングを使 用することが多くなっている，以前から一部のブレードラ バー用にコーティングはされていたが，以前のものはブレ ードラバーのゴム材との密着性が弱く，すぐにはがれてし まうものが多かった．最近は摩擦係数の高いはっ水のガラ ス面にも対応できる低摩擦のコーティングや長寿命のコー ティングが使用されつつある(図14，図15)。

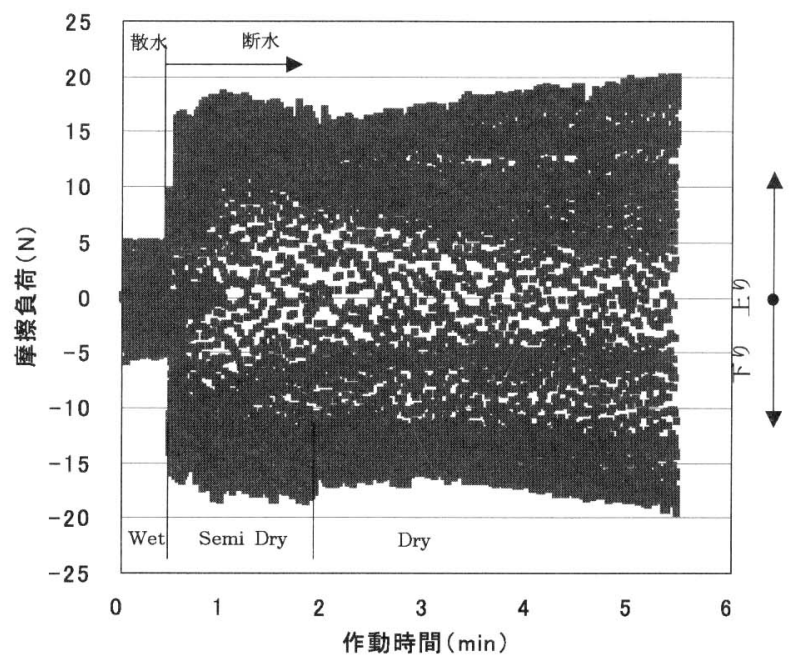

測定条件 : 洗浄面, 30 秒散水作動ののち 5 分間断水作動, $500 \mathrm{~mm}$ ワイパブレード(コーティング無)，アーム押圧：16.7 N/m

図14 ワイパブレードの摩擦負荷(害車)

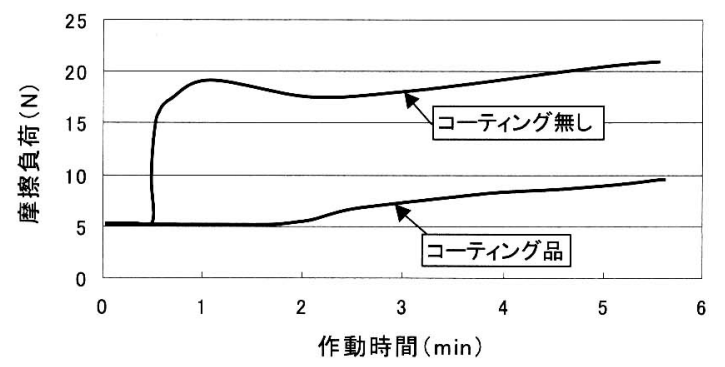

測定条件 : 洗浄面, 30 秒散水作動ののち 5 分間断水作動, $500 \mathrm{~mm}$ ワイパブレード，アーム押圧：16.7 N/m

図 15 ワイパブレードの摩擦負荷 (実車) コーティングの有無の関係

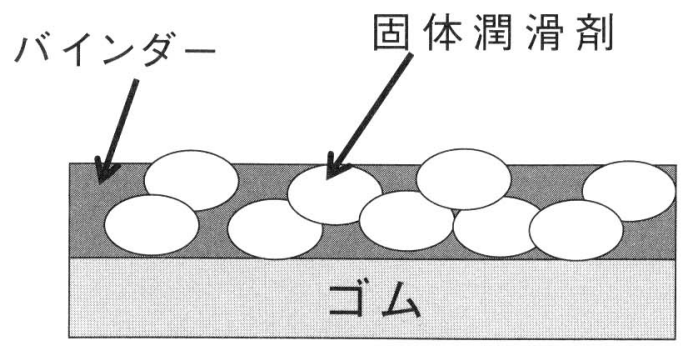

図 16 コーティングの概念図
コーティングは一般に固体潤滑剂とバインダーから成 り，固体潤滑剂は摩擦抵抗を下げる目的で使用され，グラ ファイト (黒鉛)・二硫化モリブデン・フッ素樹脂(PTFE) などがある.バインダーは固体潤滑甋をブレードラバーの ゴム材に密着させること及び被膜の強度を上げることを目 的に使用され，ゴム系や樹脂系のものがある．固体潤滑剤 とバインダーは溶剤に溶かして塗布するのが一般的である (図 16).

固体潤滑剤の比率が高くなると摩擦係数は下がるが，相 対的にバインダーの比率が低くなり，ゴムとの密着性は低 下し，耐久性が低下する。逆に固体潤滑剤の比率が低くな ると摩擦係数は下がらず, バインダーの摩擦係数の影響が 高くなる.

また，コーティングの付着は基本的にブレードラバーの エッジに対して異物となりうるため, コーティングの塗布 についてはエッジの直線性を損なわないように考慮しなけ ればならない。

\section{4. 寒冷地専用ブレード}

今まで一般的なワイパブレードについて述べてきたが， ここで寒冷地専用ブレードについて述べる.

寒冷地専用ブレードは，ウィンターブレード・スノーブ レードと呼ばれ寒冷地で冬期に使用される.特徴としては, 氷雪によるレバー金具の凍結を防止するために，レバー金 具を包むカバーがあることと，ブレードラバーのネック部 などの凍結を防止するために，ブレードラバーの断面形状 が凹凸のない単純な形状になっている点である(図17).

カバーの材質は耐候性を考慮して CRが多いが，最近は 熱可塑性エラストマーのものもある.

\section{5. ブレードラバーの今後について}

数年前からフラットブレードとかビームブレードと呼ば れる新しい構造のワイパブレードが使用されるようになっ てきた ${ }^{10-12)}$.この目的は外観性向上と高速性能の向上で ある. 構造としてはワイパブレードのレバー金具が大幅に
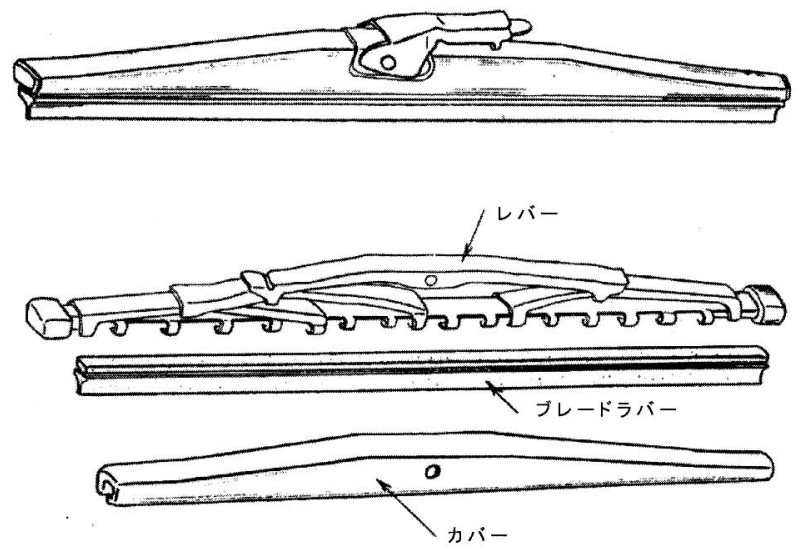

図17 ウィンターブレードの構造例 


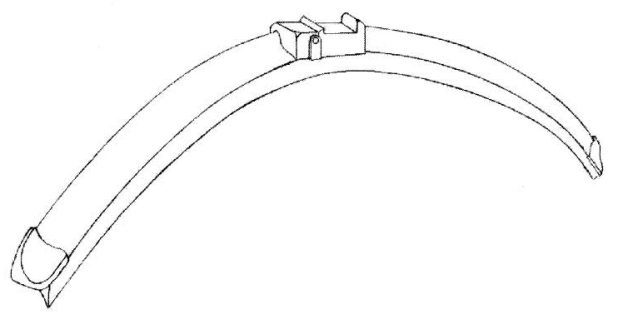

図18 フラットブレード

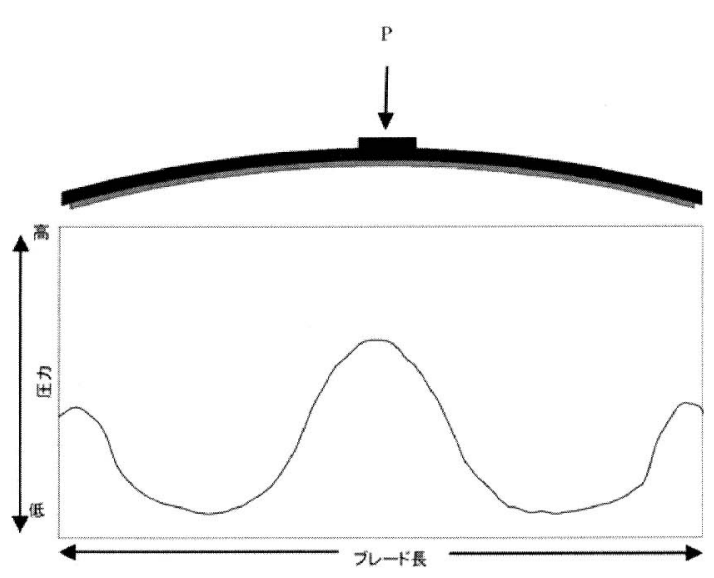

図 19 フラットブレードの圧力分布

減少またはなくなっており，ブレードラバーの上面に高速 での浮き上がり防止のための，風受け面(フィン機能)を設 けているのが特徴である(図18).

このようなブレード構造になると従来のトーナメント構 造と比較して圧力分布が悪くなる傾向があり，ブレードラ バーの接触角が変化しやすい方向である (図 19). 圧力分 布を均一にするようにワイパブレードの設計上で方策も取 られている．具体的にはバーティブラ(板バネ)の板厚や幅 を長手方向で変化させたりしているものもある13). ブレ ードラバーとしては圧力の変化に対し払しょく性や摩擦係 数が変化しにくくする工夫が必要である.

\section{6. ま と め}

ワイパブレードが自動車のガラス表面に付着した雨水・ 泥水・雪・ほこりなどを㰠ぐい取る手段として, 今後も基 本原理が大きく変わるとは考えにくい.

しかしながら，自動車室内の遮音性向上やワイパシステ
ムの変化, ワイパブレード構造の変化に伴ってブレードラ バーには，今まで以上に長寿命・低摩擦・静肃性の要求が 高まり，それらのバランスを取っていくことが必要となっ てくる.

\section{References}

1) Wiper iinkai: "Jidousya-yo Wiper Souti no Gijutsu Manual", Nippon Jidousya Buhin Kougyoukai, Tokyo (1977)

2 ) Yamamoto, Y.; Kaneta, M.: “TRIBOLOGY”, Rikougakusya, Tokyo, p.190 (1998)

3 ) Kogure,Y.: Nippon Gomu Kyoukaishi, 65, 287 (1992)

4) Jidousya-Gijutsukai: "Jidousya no Tribology", Youkendou, Tokyo, p.326 (1994)

$5)$ Yamamoto, Y.; Kaneta,M.: "TRIBOLOGY", Rikougakusya, Tokyo, p.46 (1998)

6 ) Yamamoto, Y.; Kaneta, M.: "TRIBOLOGY”, Rikougakusya, Tokyo, p.8 (1998)

7 ) Gladstone, J. H.: Hibbert,W.: J. Chem. Soc.,Trans., 53, 679 (1988)

8 ) Newkirl, A. E.: J. Am. Chem. Soc., 68, 2467 (1946)

9) Thompson,D.C.:"Mechanical Molded Goods, Neoprene and Hypalon”, E. I. DuPont de Nemours, Wilmington, DE (1955)

10) Kotlrski, T.; Merkel, W.; Leutsch, W.; Schmidt, T.: Jpn. Kohyou Tokkyo Koho 2001-502638 (2001)

11) Merkel, W.; Leutsch, W.; Kotlrski, T.; Don, F.: Jpn. Kohyou Tokkyo Koho 2001-504778 (2001)

12) Merkel, W.; Kotlrski, T.: Jpn. Kohyou Tokkyo Koho 2001504779 (2001)

13) Swanepoel, A. R.: Jpn. Kohyou Tokkyo Koho 2002-527286 (2002)

\section{日本語表記参考文献}

1) ワイパ委員会：自動車用ワイパ装置の技術マニュアル，日本自 動車部品工業会, 東京 (1977)

2 ) 山本雄二, 兼田楨宏 : トライボロジー, 理工学社, 東京, p.190 (1998)

3 ）小暮勇治：日本ゴム協会誌，65，287 (1992)

4 ）自動車技術会：自動車のトライボロジー，養賢堂，東京，p.326 (1994)

5 ) 山本雄二, 兼田楨宏 : トライボロジー, 理工学社, 東京, p.46 (1998)

6 ) 山本雄二, 兼田楨宏 : トライボロジー, 理工学社, 東京, p.8 (1998)

10）コトラースキー, T., メルケル, W., ロイチェ, W., シュミ ット，T．：特表2001-502638 (2001)

11）メルケル, W., ロイチェ, W., コトラースキー, T., ドン, F.：特表 2001-504778 (2001)

12）メルケル，W., コトラースキー, T. : 特表 2001-504779 (2001)

13）スワンポール，A., R. : 特表 2002-527286 (2002) 